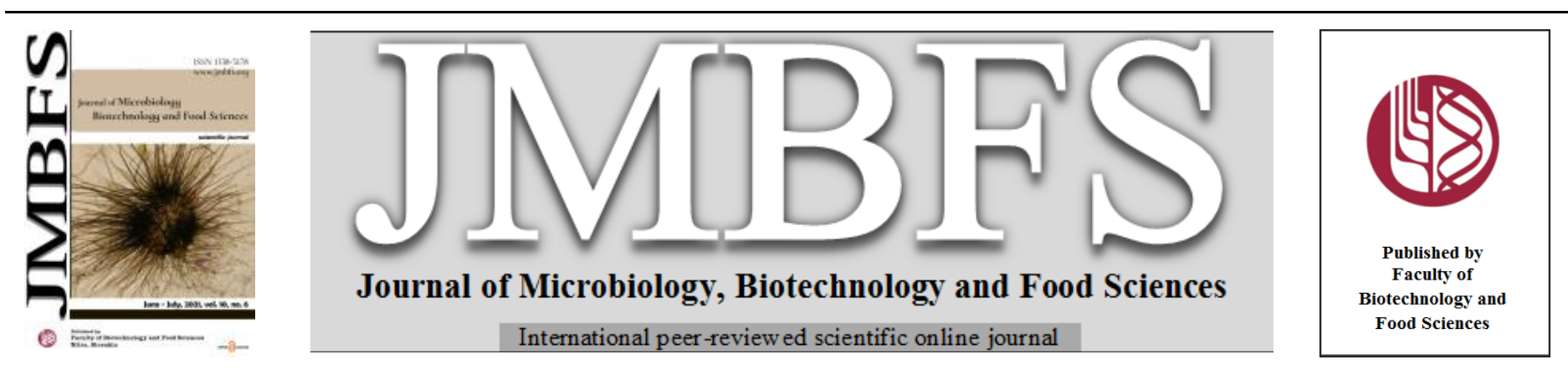

\title{
EFFECTS OF DRYING METHODS ON PHYSICO-CHEMICAL, MICROBIOLOGICAL AND SENSORY PROPERTIES OF TORPEDO SCAD (Megalaspis cordyla)
}

\author{
Md. Golam Rasul ${ }^{1}$, Ilias Ebne Kabir ${ }^{1}$, Chunhong Yuan ${ }^{2}$, A. K. M. Azad Shah ${ }^{1}$ \\ Address(es): Prof. A. K. M. Azad Shah, \\ ${ }^{1}$ Bangabandhu Sheikh Mujibur Rahman Agricultural University, Faculty of Fisheries, Department of Fisheries Technology, Gazipur 1706, Bangladesh. \\ ${ }^{2}$ Iwate University, Faculty of Agriculture, Department of Food Production and Environmental Management, 3-18-8 Ueda, Morioka 020-8550, Japan.
}

*Corresponding author: azad@bsmrau.edu.bd

https://doi.org/10.15414/jmbfs.2796

\section{ARTICLE INFO}

Received 19.3. 2020

Revised 17. 12. 2020

Accepted 28. 12. 2020

Published 1. 6. 2021

Regular article

OPEN $\partial$ ACCESS

\begin{abstract}
Generally, fish are unhygienically sun dried, which causes the considerable reduction of quality and safety of the product. The effects of drying methods on physico-chemical, microbiological, and sensory properties of Megalaspis cordyla were investigated. Fish were dried using traditional (without pre-treatment), improved (treated with 5\% salt solution), improved-TC (treated with 5\% salt solution and rubbed with turmeric and chili powder) and solar tunnel (treated with 5\% salt solution) drying methods. Sensory evaluation revealed that solar-dried products showed comparatively better quality than the products produced by other drying methods. Rehydration ability of solar dried products was comparatively higher than other dried products. Moisture content of dried M. cordyla was ranged from 16.28\% to $21.30 \%$. However, no significant $(\mathrm{p}>0.05)$ variation was found in protein, lipid and ash content on dry matter basis. Significantly (p $<0.05)$ the lowest peroxide value, acid value and carbonyl value were observed in solar dried products. In contrast, comparatively higher amount of PUFAs were found in solar dried products followed by improved, improved-TC and traditionally produced dried fish. The aerobic plate count of dried M. cordyla varied between $2.04 \mathrm{log}$ CFU/g and $5.71 \mathrm{log}$ CFU/g. Results of this study suggested that the dried fish produced by solar tunnel drying method showed comparatively better quality than other drying methods for the consumer's safety.
\end{abstract}

Keywords: Megalaspis cordyla, drying methods, sensory properties, chemical composition, fatty acid, lipid oxidation

\section{INTRODUCTION}

Sun drying is a traditional and important processing method to preserve seafood since ancient times. Different drying methods have different effects on dried fish. During the drying process, seafood is exposed to light, heat, and air, which can affect the nutritional quality of the product. For domestic market, about $20 \%$ of the artisanal catch is being dried by traditional sun drying method (Hasan et al., 2016a) and Bangladesh earns 425.20 million BDT of foreign currency by exporting 3143.93 metric ton of dried fish in the year of 2017-18 (DoF, 2018). However, sensory and nutritional quality of those dried products are not satisfactory for human consumption due to unhygienic processing and handling of fish, inappropriate drying methods and time, insects' infestation, microbial and fungal growth, indiscriminate use of various types of pesticides, improper storage and lipid oxidation of dried fish (Reza et al., 2005; Chaijan et al., 2006; Hasan et al., 2016b; Rasul et al, 2020).

Lipids of marine fish are rich in n-3 long chain polyunsaturated fatty acids (Aidos et al, 2002; Passi et al, 2002) are very prone to oxidation that is also favored by sun drying. Lipid oxidation has an important role to change the quality and safety of products. Besides, lipid oxidation products have adverse effects on human body (Larsson et al., 2015; Bellanti et al., 2017). Now-a-days, people are more concerned about the health and nutritive value of the food product when they buy them for their consumption (Hossain et al., 2008; Bhuiyan et al., 2008). Therefore, fish processors should be aware about processing time, technique and finally the nutritional quality and safety of the dried products. To improve the quality of dried fish, various drying techniques have been established with diverse pre-treatments. During drying of fish powdered chili pepper and turmeric powder have been reported to be used against insect infestation (Nowsad, 2005; Rahman et al., 2017). In addition, solar tunnel drying method is used to produce quality dried fish, which do not need any power from electrical grid or fossil fuels (Nowsad, 2003). Different kinds of solar tunnel dryer have been designed and examined for fish drying (Ogbonnaya, 2009). Thus, a suitable drying method of fish is crucial to improve nutritional value by retarding the microbial growth and lipid oxidation. Furthermore, it is necessary to ensure quality and safe dried fish for the consumers as well as earning more foreign currencies.

Torpedo scad, Megalaspis cordyla (locally known as Kauwa fish) is belongs to the family of Carangidae, mostly found in coastal and marine waters in Bangladesh. The taste of this fish is very poor that is why consumers do not prefer to eat it although the price of this fish is comparatively cheaper than other marine fishes. Generally, many people do not like to eat some marine fish species as fresh but they prefer these fish as dried for its characteristic taste and flavor So far, there is no dried fishery products prepared from this species. Thus, there is an opportunity to produce dried product of this species that might improve the quality and taste of the final products and it might be a value addition of this species. Therefore, this study was aimed to investigate the effects of drying techniques on the physico-chemical, microbiological and sensory characteristics of M. cordyla.

\section{MATERIALS AND METHODS}

\section{Fish samples collection}

Fresh Torpedo scad, $M$. cordyla (length $25.76 \pm 5.32 \mathrm{~cm}$ and weight $413.36 \pm$ $9.81 \mathrm{~g}$ ) were bought from the local fish market, Gazipur, and were brought with proper icing to the Fish Processing Laboratory of Bangabandhu Sheikh Mujibur Rahman Agricultural University (BSMRAU), Gazipur, Bangladesh.

\section{Drying methods}

M. cordyla was dried using four different methods of drying- namely traditional sun drying, sun drying on ring tunnel dryer, sun drying on ring tunnel dryer with turmeric and chili powder, and solar tunnel drying, which are designated as traditional, improved, improved-TC and solar, respectively. Fish were dried under sunlight and air during day time (10:00 am to 4:00 pm for 7 days) until the water content was reduced to approximately $16-20 \%$ during the month of February, 2019 (average day temperature $24{ }^{\circ} \mathrm{C}$ ). Dried fish were then packaged in an air tight polythene bag and stored at $-20{ }^{\circ} \mathrm{C}$ until further analyses. 


\section{a. Traditional sun drying}

Fish were dressed and hanged on a rope. In this method, fish were not cleaned and immersed in a salt solution. The dried fish were kept in a low temperature freezer $\left(-20{ }^{\circ} \mathrm{C}\right)$ until use.

\section{b. Sun drying on ring tunnel dryer}

For the improved sun drying method, ring tunnel dryer was prepared according to Nowsad (2005). Briefly, ring tunnel dryer was made using iron poles and mosquito nets. Before hanging on the ring, fishes were eviscerated, rinsed with clean water and immersed in a solution containing $5 \%$ salt for $10 \mathrm{~min}$.

\section{c. Sun drying on ring tunnel dryer with turmeric and chili powder}

For this type of sun drying, ring tunnels were prepared as the previous one. In this method, fishes were eviscerated, rinsed with clean water and immersed in a solution containing $5 \%$ salt for $10 \mathrm{~min}$, and rubbed with turmeric $(0.1 \%)$ and chili $(0.1 \%)$ powder solution. Then, treated fish were hanged in the ring tunnel dryer but no mosquito net was used.

\section{d. Drying in a solar tunnel dryer}

Solar tunnel drying is an atmosphere friendly method of fish drying. Solar tunne dryer was prepared according to the method of Nowsad (2005). The fishes were eviscerated, rinsed with clean water and immersed in a solution containing $5 \%$ salt for $10 \mathrm{~min}$. Then the fish was hanged on a solar tunnel dryer.

\section{Determination of sensory characteristics}

Sensory characteristics of dried fishes were evaluated by following Rasul $\boldsymbol{e t} \boldsymbol{a l}$. (2018). Individual sensory booths were used to perform sensory evaluation. Representative dried fish were served to assess the physical characteristics by a panel of 10 members (ages from 22 to 36 years) from the Department of Fisheries Technology of BSMRAU.

\section{Determination of water reconstitution}

Water reconstitution behaviors of dried fishes were measured by following Majumdar et al. (2017). Briefly, dried fish sample (8-10 g) was dipped in a water bath with varying temperature (ambient temperature $\left(24{ }^{\circ} \mathrm{C}\right.$ to $29{ }^{\circ} \mathrm{C}$ ), 40 ${ }^{\circ} \mathrm{C}$ and $60{ }^{\circ} \mathrm{C}$ ). The dried fish was soaked into water for $60 \mathrm{~min}$. The soaked sample was removed every $15 \mathrm{~min}$ and again weighed. The percentage of moisture uptake in rehydrated fish was estimated using the following equation:

$$
\text { Water Reconstitution }(\%)=\frac{\mathrm{Wr}-\mathrm{Wi}}{\mathrm{Wi}} \times 100
$$

Where, $\mathrm{Wi}=$ Weight of the dried sample; $\mathrm{Wr}=$ Final weight of the rehydrated sample

\section{pH measurement}

For the determination of $\mathrm{pH}$, sample ( $10 \mathrm{~g}$ ) was grinded in a blender with $100 \mathrm{~m}$ of deionized water and homogenate was prepared. $\mathrm{pH}$ of the homogenate was directly measured using a pH meter (MeterLab PHM 310, China).

\section{Biochemical analysis}

\section{Analysis of proximate composition}

The proximate composition (moisture, crude protein, crude lipid and ash) was determined following AOAC (2002) method.

\section{Extraction of total lipid}

Extraction of total lipid from dried fish samples were done by Bligh and Dyer (1959) method using a solvent mixture of chloroform: methanol: distilled water (10:5:3). The extracted lipid was redissolved in chloroform and kept at $-20^{\circ} \mathrm{C}$ for further use.

\section{Acid value measurement}

Acid value (AV) was measured using AOAC (2002) method. Total lipid (0.5 g) was diluted with a solution of ethanol and diethyl ether (1:1) and potassium hydroxide $(0.01 \mathrm{~N})$ was used for titration. The results were reported as $\mathrm{mg}$ $\mathrm{KOH} / \mathrm{g}$ lipid.

\section{Peroxide value determination}

The peroxide value (PV) of total lipid was measured using AOAC (2002) method. Briefly, $0.5 \mathrm{~g}$ of total lipid was diluted with a solution of glacial acetic acid and chloroform $(3: 2)$. Saturated potassium iodide $(0.5 \mathrm{~mL})$ was mixed to the solution and stored for $10 \mathrm{~min}$ at dark condition. Freshly prepared starch solution $(1 \%)$ and deionized water $(30 \mathrm{~mL})$ was added to it and sodium thiosulfate $(0.01$ $\mathrm{N}$ ) was used for titration. The PV value was stated as meq $/ \mathrm{kg}$ of lipid.

\section{Carbonyl value estimation}

Carbonyl value (CV) of total lipid was measured following the method of Endo et al. (2003) with slight modification. A standard curve was prepared using noctylaldehyde and carbonyl compounds were expressed as $\mu \mathrm{M} / \mathrm{g}$ of lipid.

\section{Analysis of fatty acid composition}

Total lipids were transformed to fatty acid methyl esters (FAME) by the method of Prevot and Mordret (1976). Briefly, lipids were diluted in $n$-hexane (1 $\mathrm{ml})$, and $2 \mathrm{~N}-\mathrm{NaOH}$ methanolic solution $(0.2 \mathrm{ml})$ was added to it. The mixture was heated for 20 seconds at $50{ }^{\circ} \mathrm{C}$ and then $2 \mathrm{~N}-\mathrm{HCl}$ methanolic solution $(0.2 \mathrm{ml})$ was added. The upper layer, FAME was taken and analyzed on a Gas Chromatograph (GC 353, GL Science Inc., Tokyo, Japan) with a $0.5 \mu \mathrm{m}$ PEG$20 \mathrm{M}$ liquid phase-coated G-300 column (40 $\mathrm{m} \times 1.2 \mathrm{~mm}$ i.d.) and quantified by FID detector. The injector, detector and column temperature were 240, 250 and $170{ }^{\circ} \mathrm{C}$, respectively. The fatty acids were identified by comparison with the retention times of known standards (GL Sciences Inc., Tokyo, Japan).

\section{Aerobic plate count (APC)}

APC of bacteria in dried $M$. cordyla fish was estimated using spread plate count technique. Briefly, $10 \mathrm{~g}$ dried fish sample was blended with $90 \mathrm{ml}$ of physiological saline $(0.85 \% \mathrm{NaCl})$ for preparing consecutive decimal dilution. Each dilution of fish homogenate cultured in sterile plate count ager following spread plate method and incubated at $37^{\circ} \mathrm{C}$ for 24 hours. Bacterial colonies (30300 colonies) were then counted as cfu/g and converted it as $\log \mathrm{CFU} / \mathrm{g}$ (Barraw and Feltheam, 1993).

\section{Statistical analysis}

All the data were reported as mean \pm standard deviation (SD). Data were analyzed using ANOVA followed by Duncan's multiple range test using Statistix 10 (Analytical Software, Tallahassee, FL, USA). A significant difference was considered at the level of $\mathrm{p}<0.05$.

\section{RESULTS AND DISCUSSION}

\section{Sensory characteristics of dried M. cordyla}

The sensory characteristics of dried fishery products depends on the freshness of the raw materials. Influence of drying techniques on sensory properties of dried M. cordyla is presented in Table 1 . Traditionally produced dried fish showed the highest scores $(\mathrm{p}<0.05)$ of color, odor and texture when compared with other drying methods. It has been reported that the dried fish having higher sensory scores indicate poor quality (Rasul et al., 2018). In this study, superior quality of dried M. cordyla was found in solar dried product followed by improved, improved-TC and traditional dried product. However, there was no insect infestation noticed among all the dried products. Similar findings were also observed in solar dried Puntius sophore and Mystus gulio than sun-dried products in India (Nath et al., 2013).

Table 1 Effect of drying methods on sensory properties of $M$. cordyla $^{l}$

\begin{tabular}{llccc}
\hline Treatment & Color & Odor & Texture & Insect Infestation \\
\hline Traditional & $5.30 \pm 0.16^{\mathrm{a}}$ & $6.30 \pm 0.16^{\mathrm{a}}$ & $2.25 \pm 0.11^{\mathrm{a}}$ & $1.00 \pm 0.00^{\mathrm{a}}$ \\
Improved & $3.22 \pm 0.13^{\mathrm{c}}$ & $1.74 \pm 0.11^{\mathrm{c}}$ & $1.47 \pm 0.10^{\mathrm{c}}$ & $1.00 \pm 0.00^{\mathrm{a}}$ \\
Improved-TC & $4.06 \pm 0.11^{\mathrm{b}}$ & $2.26 \pm 0.18^{\mathrm{b}}$ & $1.68 \pm 0.12^{\mathrm{b}}$ & $1.00 \pm 0.00^{\mathrm{a}}$ \\
Solar & $1.20 \pm 0.10^{\mathrm{d}}$ & $1.32 \pm 0.13^{\mathrm{d}}$ & $1.24 \pm 0.11^{\mathrm{d}}$ & $1.00 \pm 0.00^{\mathrm{a}}$ \\
\hline
\end{tabular}

${ }^{1}$ Each value is expressed as a mean $(1-10$ scoring $) \pm S D(n=10)$. Means with different superscripts within a column are significantly different $(\mathrm{p}<0.05)$ 


\section{Water reconstitution of dried $M$. cordyla}

The water reabsorption of dried $M$. cordyla using various drying process is depicted in Figure 1. The highest water holding capacity was found in solar dried product $\left(57.47 \%\right.$ ) after $60 \mathrm{~min}$ at $60{ }^{\circ} \mathrm{C}$, whereas $40{ }^{\circ} \mathrm{C}$ and room temperature showed $55.21 \%$ and $53.10 \%$ water uptake, respectively. Similarly, the water holding capacity of traditional, improved and improved-TC dried product was found $40.65 \%, 48.67 \%, 42.92 \%$ after $60 \mathrm{~min}$ at ambient temperature, $42.18 \%$, $50.62 \%, 45.13 \%$ at $40{ }^{\circ} \mathrm{C}$ and $45.32 \%, 52.60 \%, 47.51 \%$ at $60{ }^{\circ} \mathrm{C}$, respectively. The water-holding ability of dried fishery product also increased with the increasing of temperature and dipping time (Majumdar et al., 2018). Overall, rehydration rate of solar tunnel dried fishery products was higher than the other dried products. Akintunde (2008) found that the cell assemblage of fish muscle enlarged when the water temperature was increased that quickens the speed of water rehydration ability. It has been reported that rehydration capacity positively correlated with the texture of the dried fishery products (Reza et al., 2005) Moreover, water activity impacts the quality of the dried fish and lower water activity value enhances the water uptake capacity. Sikorski et al. (1995) reported that the water uptake has been completed within 3-15 minutes when the fish dried properly. Furthermore, rehydration ability of the dried fishery products varies with the variation of species besides time and temperature (Nurullah, 2006; Akintunde, 2008).

(A)

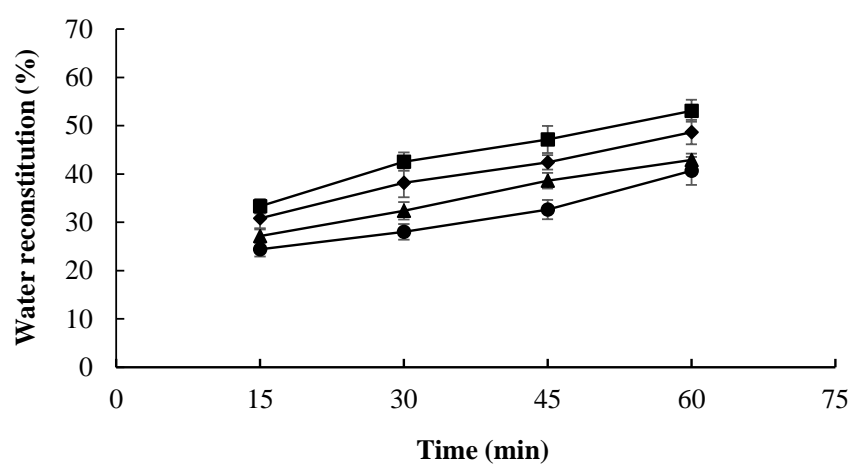

(B)

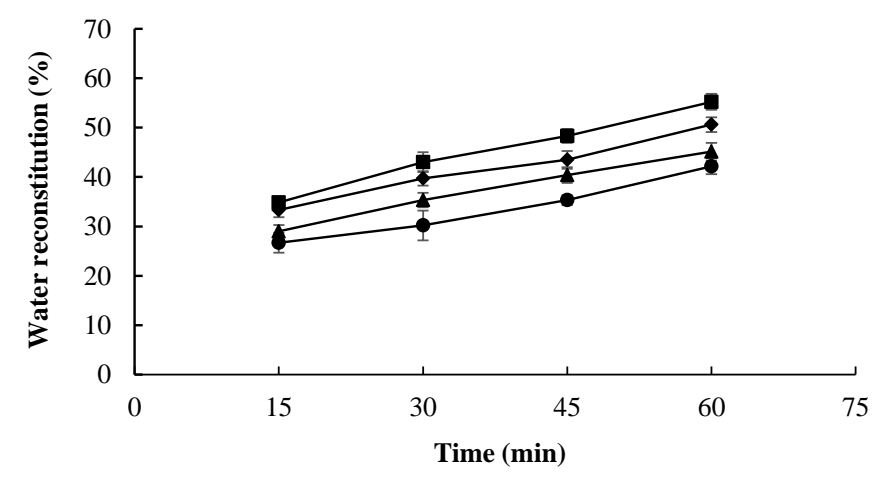

(C)

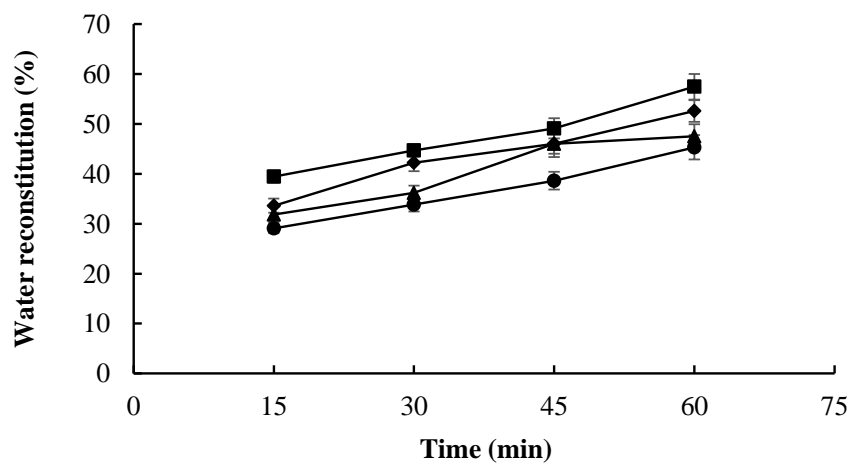

Traditional $\multimap-$ Improved $\rightarrow$ Improved - TC $\rightarrow$-Solar

Figure 1 Water reconstitution of dried $M$. cordyla at (A) room temperature (24$\left.29{ }^{\circ} \mathrm{C}\right),(\mathrm{B}) 40{ }^{\circ} \mathrm{C}$ and $(\mathrm{C}) 60^{\circ} \mathrm{C}$
pH value of dried M. cordyla

The $\mathrm{pH}$ values of dried $M$. cordyla ranged between 6.65 and 6.96 (Figure 2). Significant $(\mathrm{p}<0.05)$ variation was observed in $\mathrm{pH}$ values among the dried fish products. The traditional dried fish showed the highest $\mathrm{pH}$ value (6.96) and the lowest value (6.65) in solar dried product. It has been reported that during the drying period the $\mathrm{pH}$ value was decreased from 6.79 to 6.42 in dried herring fillet (Shah et al., 2009a). In the case of soft dried herring fillets, the $\mathrm{pH}$ value was also reduced from 6.50 to 6.35 (Nakagawa et al., 2007). Moreover, traditional air-drying at a comparatively higher temperature is unfavorable to fish muscle and results in changes in $\mathrm{pH}$ (Zyas, 1997).

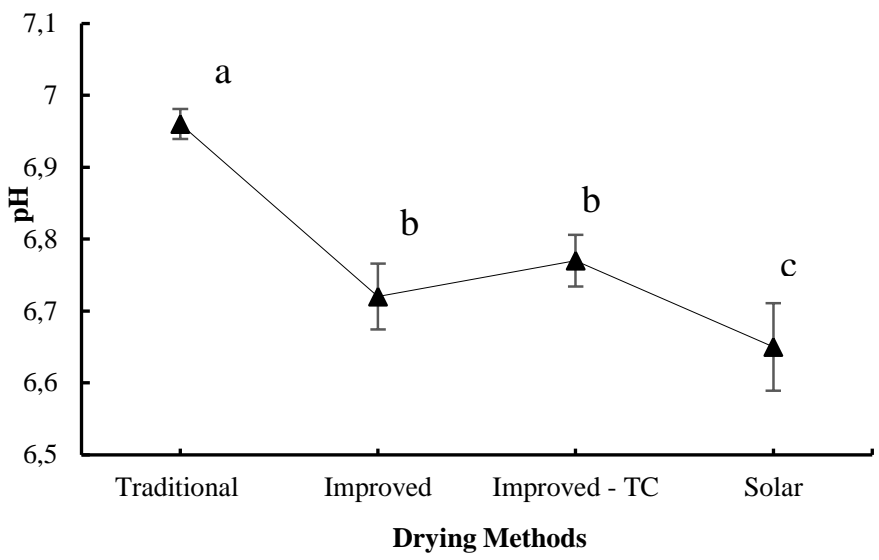

Figure $2 \mathrm{pH}$ value of $M$. cordyla in different drying methods. Each value is expressed as a mean $\pm \mathrm{SD}(\mathrm{n}=3)$. Means with different superscripts are significantly different $(\mathrm{p}<0.05)$

\section{Proximate composition of dried M. cordyla (on fresh matter basis)}

Effects of various drying process on proximate composition of $M$. cordyla are depicted in Table 2. The moisture content varied from $16.28 \%$ to $21.30 \%$. The amount of crude protein ranged from $61.67 \%$ to $65.17 \%$ and the highest value (p $<0.05)$ was found in solar dried product and the lowest value was observed in traditionally dried product. The crude lipid and ash content were ranged from $6.14 \%$ to $6.98 \%$ and $7.80 \%$ to $10.19 \%$, respectively. Comparatively higher amount of lipid was found in solar dried products that indicate lower oxidation occurred in this method. However, there was no significant $(p>0.05)$ difference observed in crude protein, crude lipid and ash on dry matter. The amount of protein in solar and sun-dried Hyperopisus bebe were $59.8 \%$ and $62 \%$, respectively (Ojutiku et al., 2009). The findings of this study coincide with the results of Immaculate et al. (2012) and Hasan et al. (2016a).

Table 2 The proximate composition of dried $M$. cordyla ${ }^{l}$

\begin{tabular}{lcccc}
\hline Treatment & Moisture & Protein & Lipid & Ash \\
\hline Traditional & $21.30 \pm$ & $61.67 \pm 0.96^{\mathrm{c}}$ & $6.14 \pm 0.14^{\mathrm{c}}$ & $7.80 \pm 0.20^{\mathrm{d}}$ \\
& $0.59^{\mathrm{a}}$ & & & \\
Improved & $18.41 \pm$ & $63.53 \pm 0.88^{\mathrm{b}}$ & $6.59 \pm$ & $9.27 \pm 0.10^{\mathrm{b}}$ \\
& $0.81^{\mathrm{b}}$ & & $0.28^{\mathrm{ab}}$ & \\
Improved - & 20.84 & $62.20 \pm 0.72^{\mathrm{bc}}$ & $6.25 \pm$ & $8.49 \pm 0.19^{\mathrm{c}}$ \\
TC & $\pm 1.28^{\mathrm{a}}$ & & $0.27^{\mathrm{bc}}$ & \\
Solar & $16.28 \pm$ & $65.17 \pm 0.86^{\mathrm{a}}$ & $6.98 \pm 0.21^{\mathrm{a}}$ & $10.19 \pm 0.14^{\mathrm{a}}$ \\
& $0.50^{\mathrm{c}}$ & & & \\
\hline
\end{tabular}

${ }^{1}$ Each value is expressed as mean \pm SD $(n=3)$. Means with different superscripts $(\mathrm{a}-\mathrm{c}=$ fresh matter; $\mathrm{e}=$ dry matter $)$ within a column are significantly different $(\mathrm{p}$ $<0.05)$

\section{Lipid oxidation of dried M. cordyla}

The PV of dried M. cordyla was varied from 12.86 to $15.40 \mathrm{meq} / \mathrm{kg}$ of lipid in various drying techniques (Figure 3 ). The lowest peroxide value $(p<0.05)$ was found in solar tunnel dried M. cordyla and the value was $12.86 \mathrm{meq} / \mathrm{kg}$ of lipid. In contrast, the highest peroxide value was $(\mathrm{p}<0.05)$ found in traditional dried product (15.40 meq/kg of lipid) followed by improved-TC (15.07 meq/kg of lipid) and improved (14.19 meq/kg of lipid) drying method. All these values were in acceptable limit (the value less than or equal to meq/kg of oil) for human consumption (Connell, 1995). Shah et al. (2009) revealed that the peroxide value $(5.52 \mathrm{meq} / \mathrm{kg}$ to $11.86 \mathrm{meq} / \mathrm{kg}$ ) of herring (Clupea pallasii) lipids raised with the increasing of drying time. Moreover, lipids were degraded during storage of dried fishes, which effect on fish flavor owing to the presence of PUFAs (Alasalvar $\boldsymbol{e t}$ al., 2005; Majumdar et al., 2018). 


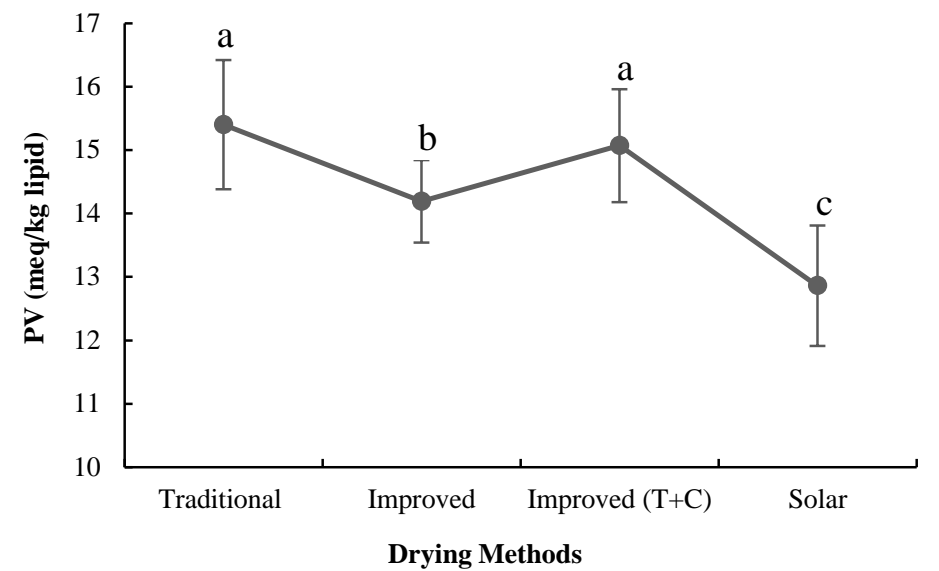

Figure 3 Peroxide value of $M$. cordyla in various drying methods. Each value is expressed as a mean $\pm \operatorname{SD}(n=3)$. Means with different superscripts within a line are significantly different $(\mathrm{p}<0.05)$

In addition to peroxide value, acid value was determined to measure the level of lipid hydrolysis in dried fishes. Acid value of traditional, improved, improved-TC and solar tunnel dried $M$. cordyla were $14.82,12.25,12.48$ and $11.46 \mathrm{mg} \mathrm{KOH} / \mathrm{g}$ of lipid, respectively (Figure 4). It is known that the higher acid value indicates poor quality of a food product. Majumdar et al. (2017) observed that the acid value of sun-dried Wallago attu, Channa striatus and Glossogobius giuris was ranged from $16.23 \mathrm{meq} / \mathrm{kg}$ to $18.64 \mathrm{meq} / \mathrm{kg}$ lipid, which was agreed to the present findings. Rasul et al. (2019) also observed similar results of peroxide value and acid value in dried Trichogaster fasciata. Free fatty acids were usually formed when lipolysis take place in fish muscle lipid (Pacheco-Aguilar $\boldsymbol{e t}$ al., 2000). Moreover, oxidation of unsaturated fatty acids develops off-odors and off flavors, which could deteriorate the nutritional quality and safety of the food product (Mbunda, 2013). The lipid oxidation primary products in fish reduce its protein digestibility (Boler et al., 2012). Formation of secondary oxidation products can cause aging, membrane injury, cardiovascular diseases, atherosclerosis and tumor growth (Cho, 2005).

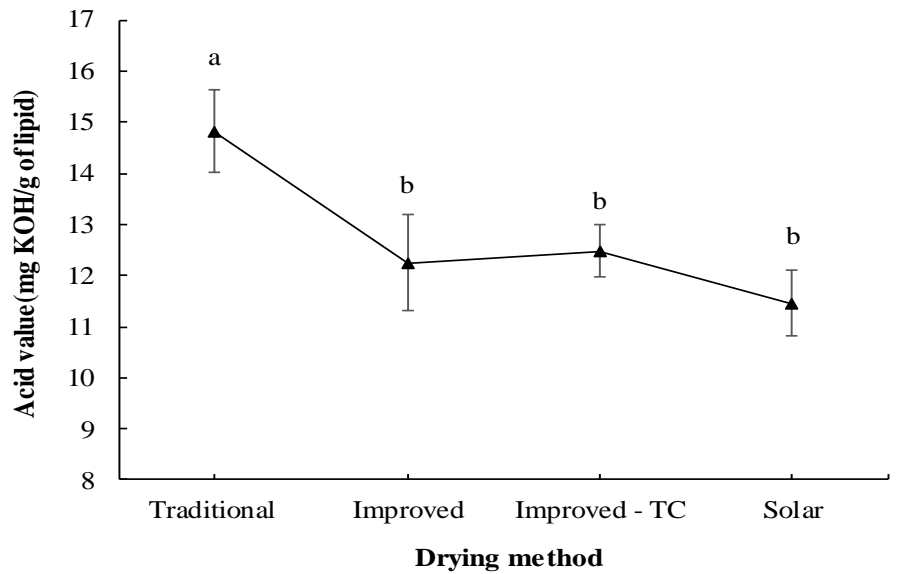

Figure 4 Acid value of $M$. cordyla in various drying methods. Each value is expressed as a mean $\pm \operatorname{SD}(n=3)$. Means with different superscripts within a line are significantly $(\mathrm{p}<0.05)$ different

$\mathrm{CV}$ of dried $M$. cordyla produced by various drying methods is depicted in Figure 5. The CV was varied between 6.21 and $8.22 \mu \mathrm{M} / \mathrm{g}$ of lipid. The highest $\mathrm{CV}$ was found in traditional dried product and the lowest value was observed in solar dried product. This result suggested that the lowest oxidation occurred in solar dried fish. However, improved and improved-TC dried product did not show any significant difference. Shah et al. (2009) reported that the CV of dried herring ranged from 4.66 to $7.27 \mu \mathrm{M} / \mathrm{g}$ of lipid that was agreed to our results.

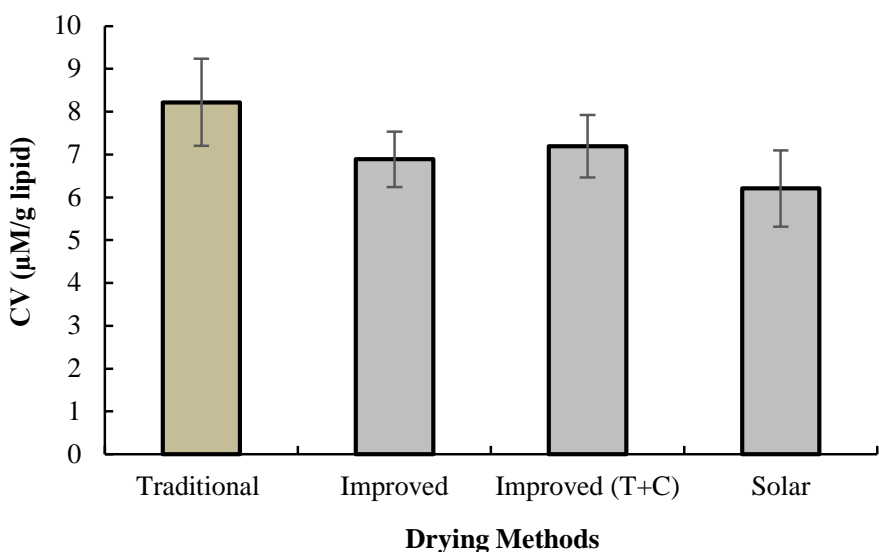

Figure 5 Carbonyl value $(\mathrm{CV})$ of $M$. cordyla in various drying methods. Each value is expressed as a mean $\pm \mathrm{SD}(\mathrm{n}=3)$

Fatty acid profile of total lipid in dried M. cordyla are presented in Table 3. The dominant fatty acids of lipids were cetoleic acids $(22: 1 \mathrm{n}-11)$, palmitic acid (16:0), stearic acid (18:0), oleic acid (18:1n-9) and docosahexaenoic acid (DHA, 22:6n3). Monounsaturated Fatty Acids (MUFAs) were the major category that varied between $47.33 \%$ and $53.83 \%$ of total lipid. The PUFAs varied from 26.74$30.45 \%$ in which DHA and EPA were prominent. Significantly the highes PUFAs was found in solar dried product and the lowest was found in traditional dried products, which suggested that more lipid oxidation occurred in traditional dried products. Shah et al. (2009) also observed that PUFAs was reduced due to lipid oxidation during drying of herring fillet. The significant variations of PUFAs in solar dried and experimental dried silverside fish (Atherina lagunae) were also influenced by various drying methods (Selmi et al., 2010). Moreover, rough handling, unhygienic processing and storage of fish and fishery products can prompt oxidation of lipid as well as affect the PUFAs that are very sensitive to oxidative rancidity. It has been reported that generation of off-flavor and offodor in fish muscle might be due to the oxidation of PUFAs, which influence overall sensory properties of fish (Ramanathan and Das, 1992; Maqsood et al., 2012). The findings of this study coincide with the results of Aro et al. (2000), who reported that PUFAs of lipids are influenced by season and processing of Baltic herring.

Table 3 Changes in fatty acid composition ( $\mathrm{mg} / \mathrm{g}$ dry matter) of total lipids in $M$. cordyla in various drying methods

\begin{tabular}{|c|c|c|c|c|}
\hline \multirow{2}{*}{ Fatty acid } & \multicolumn{4}{|c|}{ Drying methods } \\
\hline & Traditional & Improved & Improved-TC & Solar \\
\hline 14:0 & $1.67 \pm 0.16^{\mathrm{c} *}$ & $2.10 \pm 0.33^{\mathrm{b}}$ & $2.06 \pm 0.07^{\mathrm{b}}$ & $3.09 \pm 0.02^{\mathrm{a}}$ \\
\hline $16: 0$ & $9.59 \pm 0.13^{\mathrm{b}}$ & $9.28 \pm 1.42^{\mathrm{ab}}$ & $9.77 \pm 0.05^{\mathrm{b}}$ & $10.32 \pm 0.04^{\mathrm{a}}$ \\
\hline 18:0 & $6.42 \pm 0.10^{\mathrm{c}}$ & $6.70 \pm 0.49^{\mathrm{ab}}$ & $6.74 \pm 0.04^{\mathrm{b}}$ & $7.04 \pm 0.02^{\mathrm{a}}$ \\
\hline $20: 0$ & $0.19 \pm 0.01^{\mathrm{c}}$ & $0.32 \pm 0.05^{\mathrm{a}}$ & $0.26 \pm 0.04^{\mathrm{b}}$ & $0.27 \pm 0.01^{\mathrm{b}}$ \\
\hline$\Sigma$ saturated & $17.87 \pm 0.33^{\mathrm{bc}}$ & $18.40 \pm 2.29^{b}$ & $18.83 \pm 0.08^{b}$ & $20.72 \pm 0.02^{\mathrm{a}}$ \\
\hline $14: 1 n-9$ & $0.52 \pm 0.01^{\mathrm{a}}$ & $0.40 \pm 0.12^{\mathrm{a}}$ & $0.18 \pm 0.02^{\mathrm{b}}$ & $0.16 \pm 0.01^{b}$ \\
\hline $16: 1 n-9$ & $2.41 \pm 0.17^{\mathrm{c}}$ & $1.85 \pm 0.47^{\mathrm{c}}$ & $2.78 \pm 0.11^{\mathrm{b}}$ & $4.23 \pm 0.03^{\mathrm{a}}$ \\
\hline 18:1n-9 & $5.11 \pm 0.09^{b}$ & $5.89 \pm 0.83^{b}$ & $6.99 \pm 0.11^{\mathrm{a}}$ & $7.04 \pm 0.03^{\mathrm{a}}$ \\
\hline $20: 1 n-9$ & $1.47 \pm 0.19^{c}$ & $3.44 \pm 0.24^{\mathrm{a}}$ & $2.90 \pm 0.04^{\mathrm{b}}$ & $3.32 \pm 0.03^{\mathrm{a}}$ \\
\hline $22: 1 \mathrm{n}-11$ & $44.32 \pm 1.33^{\mathrm{a}}$ & $39.80 \pm 5.31^{\mathrm{ab}}$ & $37.92 \pm 1.31^{\mathrm{b}}$ & $32.58 \pm 0.33^{\mathrm{c}}$ \\
\hline \multicolumn{5}{|l|}{$\Sigma$} \\
\hline $\begin{array}{l}\text { monounsatur } \\
\text { ated }\end{array}$ & $53.83 \pm 1.36^{\mathrm{a}}$ & $51.38 \pm 4.15^{\mathrm{ab}}$ & $50.77 \pm 1.16^{\mathrm{b}}$ & $47.33 \pm 0.34^{b}$ \\
\hline $14: 2$ & $0.19 \pm 0.02^{\mathrm{c}}$ & $0.14 \pm 0.11^{\mathrm{c}}$ & $0.59 \pm 0.01^{\mathrm{a}}$ & $0.50 \pm 0.01^{\mathrm{b}}$ \\
\hline $16: 2$ & $2.16 \pm 0.06^{\mathrm{c}}$ & $1.63 \pm 0.33^{\mathrm{d}}$ & $2.53 \pm 0.05^{\mathrm{b}}$ & $2.92 \pm 0.03^{\mathrm{a}}$ \\
\hline $16: 3$ & $0.74 \pm 0.03^{\mathrm{a}}$ & $0.42 \pm 0.07^{\mathrm{b}}$ & $0.41 \pm 0.02^{\mathrm{b}}$ & $0.45 \pm 0.02^{\mathrm{b}}$ \\
\hline $18: 2 n-6$ & $0.52 \pm 0.03^{\mathrm{c}}$ & $0.82 \pm 0.24^{\mathrm{ab}}$ & $0.71 \pm 0.04^{\mathrm{b}}$ & $1.00 \pm 0.01^{\mathrm{a}}$ \\
\hline $18: 3 n-6$ & $0.19 \pm 0.01^{c}$ & $0.32 \pm 0.13^{\mathrm{b}}$ & $0.48 \pm 0.09^{\mathrm{ab}}$ & $0.61 \pm 0.10^{\mathrm{a}}$ \\
\hline $18: 4 n-3$ & $0.23 \pm 0.01^{\mathrm{c}}$ & $0.29 \pm 0.05^{\mathrm{bc}}$ & $0.32 \pm 0.02^{\mathrm{b}}$ & $0.66 \pm 0.06^{\mathrm{a}}$ \\
\hline $20: 3 n-6$ & $0.96 \pm 0.06^{\mathrm{a}}$ & $0.49 \pm 0.13^{\mathrm{d}}$ & $0.88 \pm 0.01^{\mathrm{b}}$ & $0.73 \pm 0.02^{\mathrm{c}}$ \\
\hline $20: 4 n-6$ & $1.26 \pm 0.14^{\mathrm{b}}$ & $2.21 \pm 0.19^{\mathrm{a}}$ & $1.29 \pm 0.05^{\mathrm{b}}$ & $1.31 \pm 0.02^{\mathrm{b}}$ \\
\hline $20: 5 n-3$ & $2.29 \pm 1.44^{\mathrm{ab}}$ & $1.40 \pm 0.30^{\mathrm{b}}$ & $1.74 \pm 0.05^{\mathrm{bc}}$ & $2.26 \pm 0.06^{\mathrm{a}}$ \\
\hline $22: 2$ & $4.37 \pm 0.85^{\mathrm{ab}}$ & $6.19 \pm 1.27^{\mathrm{a}}$ & $3.30 \pm 0.10^{\mathrm{bc}}$ & $3.29 \pm 0.02^{\mathrm{c}}$ \\
\hline $22: 3$ & $0.88 \pm 0.05^{\mathrm{a}}$ & $0.92 \pm 0.20^{\mathrm{a}}$ & $0.92 \pm 0.03^{\mathrm{a}}$ & $0.95 \pm 0.02^{\mathrm{a}}$ \\
\hline $22: 4 n-6$ & $3.61 \pm 0.84^{\mathrm{ab}}$ & $4.32 \pm 0.34^{\mathrm{a}}$ & $4.14 \pm 0.29^{\mathrm{a}}$ & $3.31 \pm 0.12^{\mathrm{b}}$ \\
\hline $22: 6 n-3$ & $9.34 \pm 0.31^{\mathrm{b}}$ & $9.43 \pm 1.76^{\mathrm{b}}$ & $11.44 \pm 0.18^{\mathrm{b}}$ & $12.46 \pm 0.15^{\mathrm{a}}$ \\
\hline$\Sigma$ & & & & \\
\hline $\begin{array}{l}\text { polyunsatura } \\
\text { ted }\end{array}$ & $26.74 \pm 1.67^{\mathrm{bc}}$ & $28.58 \pm 1.83^{\mathrm{ab}}$ & $28.48 \pm 0.86^{\mathrm{b}}$ & $30.45 \pm 0.36^{\mathrm{a}}$ \\
\hline Others & $1.56 \pm 0.16^{\mathrm{ab}}$ & $1.64 \pm 0.27^{\mathrm{ab}}$ & $1.92 \pm 0.29^{\mathrm{a}}$ & $1.50 \pm 0.03^{\mathrm{b}}$ \\
\hline
\end{tabular}

*Different characters in the same row denote significantly different $(\mathrm{p}<0.05)$ 


\section{Microbial load of dried M. cordyla}

Quantitative microbiological analysis is a good indicator to determine the dried fish quality. The APC was varied from 2.04 to $5.71 \mathrm{log}$ CFU/g in the dried fish produced by different drying methods (Figure 6). Traditional dried product showed the highest $(p<0.05)$ APC and the lowest APC was observed in solar dried product. The standard APC for fresh fish is $7 \mathrm{log}$ CFU/g (Ojagh et al. 2010). Mansur et al. (2013) found that the APC of sun-dried fish was varied from 1.84 to $5.3 \log$ CFU/g. Moreover, it has been reported that the APC of some solar dried marine fish products were ranged between 3.27 and $4.49 \mathrm{log} \mathrm{CFU} / \mathrm{g}$ (Reza et al., 2009).

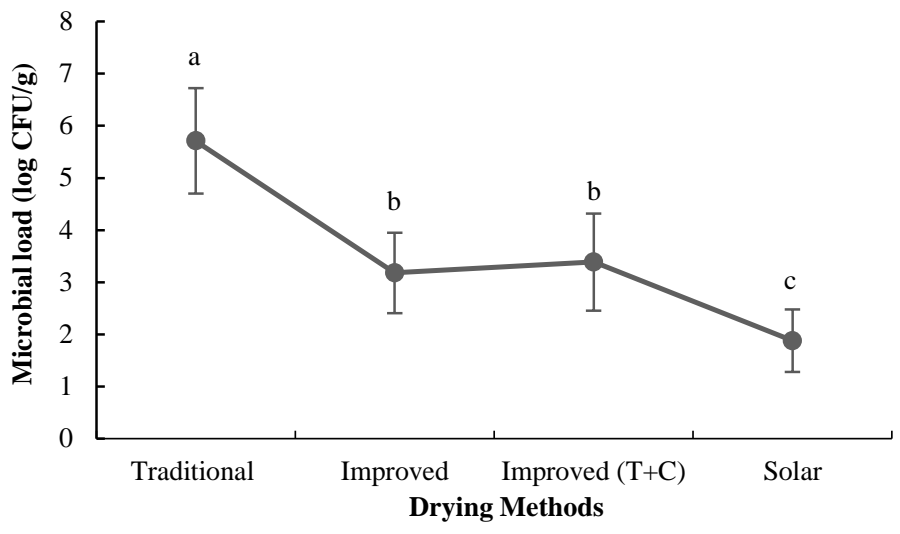

Figure 6 Microbial load of dried M. cordyla. Each value is expressed as a mean $\pm \mathrm{SD}(\mathrm{n}=3)$. Means with different superscripts within a line are significantly ( $\mathrm{p}$ $<0.05)$ different

\section{CONCLUSION}

The biochemical quality of dried torpedo scad was varied with the variation of drying process. Sensory characteristics, water reconstitution, $\mathrm{pH}$, proximate composition, lipid quality and bacterial count were highly acceptable for the solar dried fish and poor quality was found in traditional dried product. The acceptability of the dried product's quality was solar > Improved > Improved-TC $>$ traditional. Therefore, it can be concluded that solar drying method produced comparatively better quality dried fish than other drying methods.

Conflicts of interest: The authors declare that they have no conflict of interest.

Acknowledgement: This work was funded by the Ministry of Science and Technology, Government of the People's Republic of Bangladesh under Grant No.: 39.009.002.01.00.057.2015-2016/922; BS-124.

\section{REFERENCES}

Aidos, I., Van Der Padt, A., Luten, J. B. \& Boom, R. M. (2002). Seasonal changes in crude and lipid composition of herring fillets, by-products, and respective produced oils. Journal of Agriculture and Food Chemistry, 16, 45894599. https://dx.doi.org/10.1021/jf0115995

Akintunde, T, Y. (2008). Effect of soaking water temperature and time on some rehydration characteristics and nutrient loss in dried bell pepper. Agricultural Engineering International: CIGR Journal, 10, 8-13.

Alasalvar, C., Taylor, A. K. D., \& Shahidi, F. (2005). Comparison of volatiles of cultured and wild sea bream (Sparus aurata) during storage in ice by dynamic headspace analysis/gas chromatography-mass spectrometry. Journal of Agricultural and Food Chemistry, 53, 2616-2622. https://dx.doi.org/10.1021/jf0483826

AOAC, Association of Official Analytical Chemists. (2002). Official methods of analysis of AOAC international. 17th Edition. Virginia, USA.

Aro, T. L., Larmo, P. S., Backman, C. H., Kallio, H. P., \& Tahvonen, R. L. (2005). Fatty acids and fat-soluble vitamins in salted herring (Clupea harengus) products. Journal of Agricultural and Food Chemistry, 53, 1482-1488. https://dx.doi.org/10.1021/jf0401221

Barraw, G. L., \& Feltham, R. K. A. (1993). Cowan and Steel's Manual for the identification of Medical Bacteria. 2nd Edition. Cambridge University Press: Cambridge, UK.

Bellanti, F., Villani, R., Facciorusso, A., Vendemiale, G., \& Serviddio, G. (2017) Lipid oxidation products in the pathogenesis of non-alcoholic steatohepatitis Free Radical Biology and Medicine, 111, 173-185. https://dx.doi.org/10.1016/j.freeradbiomed.2017.01.023

Bhuiyan, M. N. H., Bhuiyan, H. R., Rahim, M., Ahmed, K., Haque, K. M. F., Hassan, M.T., \& Bhuiyan. M. N. I. (2008). Screening of organchlorine insecticides (DDT and Heptachlor) in dry fish available in Bangladesh. Bangladesh Journal of Pharmacology, 3(2), 114-120.
Bligh, E. G., \& Dyer, W.J. (1959). A rapid method of total lipid extraction and purification. Canadian Journal of Physiology and Pharmacology, 37: 911-917. https://dx.doi.org/10.1139/o59-099

Boler, D. D., Fernandez-Duenas, D. M., Kutzler, L. W., Zhao, J., Harrell, R. J., Campion, D. R., Keith, F. K., Killefer, J., \& Dilger, A. C. (2012). Effects of oxidized coin oil and a synthetic antioxidant blend on performance, oxidative status of tissues and fresh meat quality in finishing barrows. Journal of Animal Science, 90, 5159-5169.

Chaijan, M., Benjakul, S., Visessanguan, W., \& Faustman, C. (2006). Changes of lipids in sardine (Sardinella gibbosa) muscle during iced storage. Food Chemistry, 99, 83-91. https://dx.doi.org/ 10.1016/j.foodchem.2005.07.022

Cho, S. P. (2005). Stability and quality of fish oil during typical domestic application. Project. Wonsan University of Fisheries, Korea.

Connell, J. J. (1995). Control of fish quality. 4th Edition. Oxford: Fishing News Books. England.

DoF, Department of Fisheries. (2018). Yearbook of Fisheries Statistics of Bangladesh 2017-18. Fisheries Resources Survey System (FRSS), Dhaka, Bangladesh. 35, 1-129.

Endo, Y., Tominaga, M., Tagiri-Endo, M., Kumozaki, K., Kouzui, H., Shiramasa, H., \& Miyakoshi, K. (2003). A modified method to estimate total carbonyl compounds in frying oils using $1-\mathrm{BuOH}$ as a solvent. Journal of Oleo Science, 52, 353-58. https://dx.doi.org/ 10.5650/jos.ess14201

Hasan, M. M., Rasul, M. G., Ferdausi, H. J., Trina, B. D., Sayeed, A., Shah, A K. M. A., \& Bapary, M. A. J. (2016a). Comparison of organoleptic and chemica characteristics of some traditional and improved dried fish products. Research journal of Animal, Veterinary and Fishery Sciences, 4(2), 1-6.

Hasan, M. M., Rasul, M. G., Ferdausi, H. J., Hossain, M. M., Shah, A. K. M. A., \& Bapary, M. A. J. 2016b. Present status of dried fish markets in Sylhet of Bangladesh. Progress Agriculture, 27 (2), 235-41. https://dx.doi.org/ 10.3329/pa.v27i2.29336

Hossain, M. M., Heinonen, V., \& Islam, K. M. Z. (2008). Consumption of foods and foodstuffs processed with hazardous chemicals: A case study of Bangladesh. International Journal of Consumer Studies, 32(6), 588-95. https://dx.doi.org/10.1111/j.1470-6431.2008.00690.x

Immaculate, J., Sinduja, P., \& Jamila, P. (2012). Biochemical and microbial qualities of Sardinella fimbriata sun dried in different methods. International Food Research Journal, 19, 1699-703.

Kinsella, J. E. (1987). Seafood and fish oils in human diseases. New York: Marcel Dekker Inc.

Larsson, K., Istenic, K., Wulff, T. (2015). Effect of in vitro digested cod liver oil of different quality on oxidative, proteomic and inflammatory responses in the yeast Saccharomyces cerevisiae and human monocyte-derived dendritic cells. Journal of the Science for Food and Agriculture, 95(15), 3096-106. https://dx.doi.org/10.1002/jsfa.7046

Majumdar, B. C., Afrin, F., Rasul, M. G., Khan, M., \& Shah, A. K. M. A. 2017. Comparative study of physico-chemical, microbiological and sensory aspects of some sun dried fishes in Bangladesh. Brazilian Journal of Biological Sciences, 4, 323-31. https://dx.doi.org/10.21472/bjbs.040811

Majumdar, B. C., Afrin, F., Rasul, M. G., Shaha, D. C., Shah, A. K. M. A (2018). Changes in physico-chemical, microbiological and sensory properties of sun-dried Mystus vittatus during storage at ambient temperature. Fishes, 3(3), 32; https://dx.doi.org/10.3390/fishes3030032

Mansur, M. A., Rahman, S., Khan, M. N. A., Reza, M. S., Kamrunnahar, B., \& Uga, S. (2013). Study on the quality and safety aspect of three sun-dried fish African Journal of Agricultural Research, 8(41), 5149-155. https://dx.doi.org/10.5897/AJAR12.773

Maqsood, S., Benjakul, S., \& Kamal-Eldin, A. (2012). Haemoglobin mediated lipid oxidation in the fish muscle: a review. Trends in Food Science and Technology, 28, 33-43. https://dx.doi.org/10.1016/j.tifs.2012.06.009

Mbunda, A. E. (2013). The quality changes in smoked and dried fresh water sardine (Rastrineobola argentea) and marine pelagic fish (caplin) as influenced by processing methods [final project]. http://www.unuftp.is/static/fellows/document/arnold12prf.pdf

Nakagawa, R., Noto, H., Yasokawa, D., \& Kamatani, T. (2007). Microbiological and chemical changes during the industrial soft-drying process of migaki-nishin herring. Nippon Shokuhin Kagaku Kogaku Kaishi, 54, 26-32.

Nath, K. B., Majumdar, R. K. (2013). Quality Evaluation of Solar Tent Dried Puntius sophore and Mystus gulio of North East India. Fishery Technology, 50, $146-153$.

Nowsad, A. K. M. (2003). New method of drying fish in solar fish dryer. In empowerment of coastal fishing community project; food and agricultura organization of the United Nations: Rome, Italy.

Nowsad, A. K.M. (2005). Participatory training of trainers. A new approach applied in fish processing. 1st Edition. Bangladesh Fisheries Research Forum: Dhaka, Bangladesh.

Nurullah, M., Kamal, M., Wahab, M. A., Islam, M. N., Reza MS, Thilsted, S. H., \& Mazid, M. A. (2006). Quality assessment of traditional and solar tunnel dried SIS (Small Indigenous Fish Species). Bangladesh Journal of Fisheries Research, 10(1), 63-72. 
Ogbonnaya, C. (2009). Influences of drying methods on nutritional properties of Tilapia fish (Oreochromis nilotieus). World Journal of Agricultural Sciences, 5(2), 256-258.

Ojagh, S. M., Rezaei, M., Razavi, S. H., Hosseini, S. M. H. (2010). Effect of chitosan coatings enriched with cinnamon oil on the quality of refrigerated rainbow trout. Food Chemistry, 120, 193-98. https://doi.org/10.1016/j.foodchem.2009.10.006

Ojutiku, R. O., Kolo, R. J., Mohammed, M. L. (2009). Comparative Study of Sun Drying and Solar Tent Drying of Hyperopisus bebe occidentalis. Pakistan Journal of Nutrition, 8 (7), 955-957. https://dx.doi.org/10.3923/pjn.2009.955.957 Pacheco-Aguilar, R., Lugo-Sánchez, M.E., Robles-Burgueńo, M. R. (2000) Postmortem biochemical and functional characteristic of Monterey sardine muscle stored at $0{ }^{\circ} \mathrm{C}$. Journal of Food Science, 65, 40-47. https://dx.doi.org/10.1111/j.1365-2621.2000.tb15953.x

Passi, S., Cataudella, S., Di Marco, P., De Simone, F. \& Rastrelli, L. (2002) Fatty acid composition and antioxidant levels in muscle tissue of different Mediterranean marine species of fish and shellfish. Journal of Agriculture and Food Chemistry, 50, 7314-7322. https://dx.doi.org/10.1021/jf020451y

Prevot, A. F., Mordret, F. X. (1976). Utilisation des colonnes capillaries de verre pour l'analyse des corps gras par chromatographie en phase gazeuse. Revue Francaise des Corps Gras, 23, 409-423.

Rahman, M.S., Rasul, M. G., Hossain, M. M., Uddin, W., Majumdar, B. C. Sarkar, M. S. I., \& Bapary, M. A. J. (2017). Impact of Spice Treatments on the Quality and Shelf Life of Sun Dried Taki (Channa punctatus). Journal of Chemical, Biological and Physical Sciences, 7(2), 409-420.

Ramanathan, L., \& Das, N. P. (1992). Studies on the control of lipid oxidation in ground fish by some polyphenolic natural products. Journal of Agricultural and Food Chemistry, 40, 17-21. https://dx.doi.org/10.1021/jf00013a004

Rasul, M.G., Yuan, C. \& Shah, A. K. M. A. (2020). Chemical and Microbiological Hazards of Dried Fishes in Bangladesh: A Food Safety Concern. Food and Nutrition Sciences, 11(6), 523-539. https://dx.doi.org/10.4236/fns.2020.116037

Rasul, M. G., Majumdar, B. C., Afrin, F., Bapary, M. A. J,. \& Shah, A. K. M. A (2018). Biochemical, microbiological and sensory properties of dried Silver Carp (Hypophthalmichthys molitrix) influenced by various drying methods. Fishes, 3(3), 25. https://dx.doi.org/10.3390/fishes3030025

Rasul, M. G., Majumdar, B. C., Afrin, F., Jahan, M., Yuan, C., \& Shah, A. K. M. A. (2019). Physico-Chemical, Microbiological and Sensory Changes in Sun-dried Trichogaster fasciata During Storage. Turkish Journal of Agriculture Food $\begin{array}{llll}\text { Science } \quad \text { and } & \text { Technology, } & \text { 1568-1574 }\end{array}$ https://dx.doi.org/10.24925/turjaf.v7i10.1568-1574.2589

Reza, M. S., Bapary, M. A. J., Azimuddin, K. M., Nurullah, M., \& Kamal, M. (2005). Studies on the traditional drying activities of commercially importan marine fishes of Bangladesh. Pakistan Journal of Biological Sciences, 8(9), 1303-1310. https://dx.doi.org/10.3923/pjbs.2005.1303.1310

Reza, M. S., Bapary, M. A. J., Islam, M. N., \& Kamal, M. (2009). Optimization of marine fish drying using solar tunnel dryer. Journal of Food Processing and Preservation, 33, 47-59. https://dx.doi.org/10.1111/j.1745-4549.2008.00236.x

Selmi, S., Bouriga, N., Cherif, M., Toujani, M., \& Trabelsi, M. (2010). Effects of drying process on biochemical and microbiological quality of silverside (fish) Atherina lagunae. International Journal of Food Science and Technology, 45, 1161-1168. https://dx.doi.org/10.1111/j.1365-2621.2010.02249.x

Shah, A. K. M. A., Tokunaga, C., Kurihara, H., \& Takahashi, K. (2009). Changes in lipids and their contribution to the taste of migaki-nishin (dried herring fillet) during drying. Food Chemistry, 115(3): 1011-1018 https://dx.doi.org/10.1016/j.foodchem.2009.01.02

Sikorski, Z. E., Gildberg, A., Ruiter, A. (1995). Fish Products. In: Fish and Fishery Products, composition, nutritive properties and stability. CAB International. The Netherlands.

Zyas, J. F. (1997). Functionality of protein in food. Springer-Verlag Berlin Heidelberg. New York, USA. 